https://doi.org/10.37208/tgn27125

\section{A new Scottish record of the stonefly Amphinemura standfussi (Ris, 1902) (Plecoptera: Nemouridae)}

\author{
C.R. Macadam ${ }^{1}$, A. Dixon, A. Farr \& S. Crofts \\ ${ }^{1}$ Buglife - The Invertebrate Conservation Trust, \\ Balallan House, 24 Allan Park, Stirling FK8 2QG \\ ${ }^{1}$ E-mail: craig.macadam@buglife.org.uk
}

The stonefly Amphinemura standfussi (Ris, 1902) is found throughout Great Britain. However, it tends to have a very localised distribution (Macadam, 2015). Although in Scotland nymphs of this species have been reported from Sutherland to Berwickshire, there have only been 16 records in the past 35 years (Table 1 ).

This species appears to prefer first order streams, particularly small grassy trickles, but it may also be found in larger watercourses towards the middle river (Langford \& Bray, 1969). It is typically found in areas of slow flow, and in headwaters it may occur in very slow flowing trickles and seepages (A. Dixon, pers. obs.). It favours fine substrates such as silt, and in upland areas peat, particularly where there is coarse particulate organic matter present such as dead leaves or thatch (Hynes, 1941). The preference of this species for small headwater streams may explain the lack of records, as few studies have been undertaken of these habitats (Maitland, 1999).

A targeted survey for A. standfussi was made of small first order streams in the catchment of the River Carron in Stirlingshire. An extended period of warm dry weather in June and July 2018 meant that any streams that continued to flow could be considered perennial and more likely to yield specimens of A. standfussi. Three sites were sampled on the 27th August 2018:

Site 1 - unnamed burn near Easter Cringate Cottage (NS720875).

Site 2 - unnamed burn at Easter Cringate (NS704869). Site 3 - River Carron at its source near Muir Toll (NS631819).

At each of these sites the watercourse was $0.15-0.30 \mathrm{~m}$ wide and hidden by riparian vegetation, typically rushes (Juncus spp.) and purple moor grass (Molinia caerulea). Adult stoneflies were collected by sweeping vegetation adjacent to the watercourse with an entomological sweep net. Searches typically extended 2-3 m either side of the watercourse. All stoneflies collected were retained for identification.

Five species of stonefly were recorded during the surveys (Table 2). A single adult specimen of A. standfussi was recorded from the unnamed burn at Site 2. Further searches of this watercourse for the nymphs and more adults of $A$. standfussi were undertaken on the following day. However, no further specimens were found.

\begin{tabular}{llll}
\hline Date & Location & Grid Reference & Source \\
\hline $1959-61$ & Mary Glyn's Burn & NS681889 & Maitland (1966) \\
$1959-61$ & Endrick Water at Burnfoot & NS681889 & Maitland (1966) \\
$<1983$ & River Forth at Drip Bridge & NS770955 & Bird (1983) \\
$03 / 08 / 1986$ & Burn of Latheronwheel & ND176367 & River Macrophytes Database \\
$19 / 10 / 1986$ & Burn of Latheronwheel & ND188389 & River Macrophytes Database \\
$15 / 10 / 1989$ & Black Water & NC747161 & River Macrophytes Database \\
$23 / 08 / 1990$ & Blackadder Water & NT694473 & River Macrophytes Database \\
$12 / 11 / 1990$ & Blackadder Water & NT623527 & River Macrophytes Database \\
$08 / 04 / 1997$ & River Devon at Blacklinn & NN992049 & Scottish Environment Protection Agency \\
$27 / 05 / 1997$ & River Forth at Cobleland & NS532987 & Scottish Environment Protection Agency \\
$15 / 04 / 1998$ & River Forth at Cobleland & NS532987 & Scottish Environment Protection Agency \\
$17 / 04 / 1998$ & Goodie Water downstream of B8034 & NS595996 & Scottish Environment Protection Agency \\
& Road Bridge & & \\
$21 / 04 / 1998$ & Duchray Water upstream of River & NS506013 & Scottish Environment Protection Agency \\
& Forth & & \\
$26 / 04 / 2005$ & River Forth at Cobleland & NS531986 & Scottish Environment Protection Agency \\
$26 / 04 / 2006$ & River Forth at Cobleland & NS531986 & Scottish Environment Protection Agency \\
$15 / 05 / 2007$ & River Moriston at Torgyle Bridge & NH309130 & Scottish Environment Protection Agency \\
\hline
\end{tabular}

Table 1. Scottish records of Amphinemura standfussi. 


\begin{tabular}{|c|c|c|c|}
\hline Species & $\begin{array}{c}\text { Site 1 } \\
\text { NS720875 } \\
\end{array}$ & $\begin{array}{c}\text { Site } 2 \\
\text { NS704869 } \\
\end{array}$ & $\begin{array}{c}\text { Site 3 } \\
\text { NS631819 } \\
\end{array}$ \\
\hline Amphinemura standfussi (Ris, 1902) & & $*$ & \\
\hline Isoperla grammatica (Poda, 1761) & & $*$ & \\
\hline Leuctra fusca (Linnaeus, 1758) & $*$ & $*$ & \\
\hline Nemoura cinerea (Retzius, 1783) & & $*$ & $*$ \\
\hline Nemurella pictetii Klapálek, 1900 & $*$ & $*$ & \\
\hline
\end{tabular}

Table 2. Records of stoneflies (Plecoptera) found in the catchment of the River Carron, Stirlingshire, Scotland in 2018 during this study. Grid references are given, but the specific locations of sites are described in the main text.

It would appear that $A$. standfussi can occur in very low numbers where it is found. This may explain the paucity of records for this species, and the difficulty of finding it may account for the apparent disappearance of this species from the neighbouring Endrick Water catchment (Dodd, 2011). It is anticipated that further records of A. standfussi will be made in Scotland. Further surveys should be undertaken in small slow-flowing streams and trickles to help to fully determine the distribution of this species.

\section{REFERENCES}

Bird, L.M. (1983). Records of stoneflies (Plecoptera) from rivers in Great Britain. Entomologist's Gazette 34, 101-111.

Dodd, J.A. (2011). Long-term Change in River Invertebrate Communities. Ph.D. thesis, University of Glasgow.

Hynes, H.B.N. (1941). The taxonomy and ecology of the nymphs of British Plecoptera with notes on the adults and eggs. Transactions of the Royal Entomological Society of London. 91, 459-557. https://doi.org/10.1111/j.1365-2311.1941.tb01039.x

Langford, T.E. \& Bray, E.S. (1969). The distribution of Plecoptera and Ephemeroptera in a lowland region of Britain (Lincolnshire). Hydrobiologia 34, 243271. https://doi.org/10.1007/BF00141931

Macadam, C.R. (2015). A Review of the Stoneflies (Plecoptera) of Great Britain. Species Status No. 20. Natural England Commissioned Report, NECR174.

Maitland, P.S. (1966). Studies on Loch Lomond 2: The Fauna of the River Endrick. Blackie \& Son Ltd., Glasgow.

Maitland, P.S. (1999). New horizons - new species? The invertebrate fauna of unexplored aquatic habitats in Scotland. Aquatic Conservation: Marine and Freshwater Ecosystems 9, 529-534.

https://doi.org/10.1002/(SICI)1099-0755(199911/1 2) $9: 6<529:: A I D-A Q C 382>3.0 . C O ; 2-8$ 
